\title{
POPULISM IN FOREIGN POLICY
}

\section{Angelos Chryssogelos}

\section{INTRODUCTION}

The election of Donald Trump in late 2016 to the presidency of the US has placed populism at the forefront of debates about the future direction of international affairs. Europe, Latin America, the Middle East and Asia were already engulfed in populist politics for decades. There is the growing recognition that populism today is not exclusively a phenomenon of domestic politics, but that it influences significantly outcomes of world politics as well. It thus becomes important to understand better what the rise of populism means for foreign policy. This is a challenging endeavour, given how (relatively) little attention FPA has paid to populism specifically, and party politics more generally.

The challenge is even bigger if one considers the slippery nature of the concept of populism, both in academic debates and public discourse. Analytical work on populism draws on many different theoretical traditions. The populist phenomenon also exhibits increasing empirical heterogeneity, appearing in multiple iterations in varying geographical and developmental contexts. Scholars of foreign policy and international relations who want to study the effect of populism have to deal with a varied, and sometimes convoluted, conceptual and empirical field.

I argue that scholars of foreign policy would be well served to embrace the vibrancy of conceptual debates on populism. Different conceptualizations of populism have different implications about the role of populism in a political system and, by extension, the ways it affects foreign policy outcomes. I will also argue that comparative analysis of populist foreign policy can benefit from a broader geographical and regional scope of research. While the slippery nature of the concept of populism can often appear frustrating, its variegated nature also means that it can apply to, and increase our understanding of, varying phenomena of world politics and foreign policy. 
CONCEPTUALIZING POPULISM

a) Main Theoretical Approaches

It is generally accepted that, in its core, populism promotes the juxtaposition in society of two homogeneous blocs - the 'people' and the 'elite' - whereby one (the people) is seen as inherently virtuous. Thus populism is both Manichean and moralistic in its philosophy, as it carries an instinctive distrust of elites (Canovan 1999; Taggart 2000). Beyond this core of basic premises however populism is a concept that has been studied from a variety of theoretical approaches over time.

Sociological approaches, of liberal or Marxist ilk, were prominent in the early years of research on populism. These approaches viewed populism as the outcome of and reaction to processes of modernization. Liberal approaches saw populism as an irrational reaction containing chauvinism, closed-mindedness and irresponsibility (Hofstadter 1955; Shils 1956). This view of populism dovetailed with the then mainstream view that modernization in peripheral economies was an inherently positive prospect. Thus early comparative work on populism concerned itself with developing countries in the process of modernization problematique (Ionescu and Gellner 1969).

As modernization theories came under increased scrutiny and populism started appearing also in developed countries, new and more streamlined approaches for the comparative study of populism emerged. Taggart (2000) defined populism as an 'empty shell' filled by thicker ideologies according to which the virtuous people and the corrupt elites are defined. Mudde $(2004 ; 2007)$ standardized this view for use in comparative work by conceptualizing populism as a 'thin-centred ideology'. Thicker and more consistent ideological frameworks of the right or left (e.g. socialism, liberalism or nativism) give populism its specific ideological outlook.

Work on populism in Europe has overwhelmingly focused on the populist radical right. The populist radical right is a distinct political family that combines nativism, authoritarianism and populism (Albertazzi and McDonnel 2008, Mudde 2007). Populism allowed far right parties to update 
discredited ideological features, such as racism and anti-democratic authoritarianism, by radicalizing elements of modernity like democratic representation and proliferation of social identities in increasingly diversified societies (Minkenberg 2000). The rise of the populist radical right is associated with the emergence of modernization or globalization losers (see Betz 1993 and Kriesi et al 2008 respectively), i.e. strata dislocated by social differentiation and individualization, and deterritorialization of economic and political processes. Immigration has been the touchstone of the rise of the populist radical right because it symbolizes the porousness of borders and pressures on national economies and cultures (Kriesi et al 2008).

Analogously to the far right, the post-communist far left has also tried to associate its core tenets - social justice, economic statism - with a discourse of popular emancipation against neoliberal elites. While the populist radical right defines the 'people' in cultural and ethnic terms, the populist left defines the 'people' in socioeconomic terms. It is therefore more inclusive than the populist radical right, since the latter targets opponents not only 'above' (the elites) but also 'below' the virtuous people (immigrants). Until the Great Recession of the 2000s however the populist left only enjoyed periodic successes in some countries and was generally less prominent than the populist radical right (March 2007; March and Mudde 2005).

This comparative approach has become the main reference point in the study of parties and movements in the electoral arena, especially in Europe. But the empirical variety and geographical reach of populism means that other theoretical frameworks have also been used to examine prominent cases of populism. The case of Latin America, the region with the longest and strongest tradition of populism, has long been the object of theoretically informed analysis (see indicatively Roberts 2007, Weyland 2001), and only recently has there been an effort to analyse populism in Latin America using the thin-centred ideology approach (Mudde and Rovira Kaltwasser 2011).

Populism in the United States is also difficult to classify comparatively. American populism was long associated with emancipatory, progressive and reformist politics (Nugent 1963). In the 1950s 
however scholars highlighted the anti-intellectual, irrational and conspiratorial features of populist movements (Hofstadter 1955). At the root of this divide is American populism's development largely free of explicit associations with thicker ideological traditions. Thus one may associate the populist farmers of the 1890s with 'agrarianism', or see populism as an expression of the 'Jacksonian' political tradition (Mead 2011). But even when one identifies elements that can be conventionally described as 'left-wing' or 'right-wing' these usually co-exist in the same populist movement (Kazin 2016). More generally, in the US populism appears to transcend formal partisan boundaries.

A residue of modernization theory analyses of populism has been the persistent view of populism as a problematic phenomenon (see discussion in Hadiz and Chryssogelos 2017). A response to this tendency is the work of Ernesto Laclau and his associates (Laclau 2005; Panizza 2005). Laclau viewed populism as an antagonistic logic and discourse of politics that aggregates multiple frustrated social demands around binary contests between a variously defined 'people' - a signifier that coalesces these frustrated demands - and the 'power' or 'system'. The insinuation in Laclau's work, as well as the interpretations of his followers in the so-called Essex School (Stavrakakis 2014), is that populism in its purest form is an inclusive and emancipating phenomenon that brings 'the people' back into play in political settings stifled by depoliticization and technocracy.

While thicker ideological traditions remain important for the self-perception of European populist parties, recent developments in Europe seem to vindicate the insight of critical and discursive approaches such as Laclau's that the key characteristic of populist politics is the creation of potent dividing lines between the 'people' (variously defined) and the 'system' - a divide Peter Mair some years back had conceptualized as reflecting the fundamental difference between mainstream technocratic parties of all ideological persuasions focused on 'responsible' government and antisystem parties clamouring for more 'representative' government (Mair 2009).

Comparative analysis of developments in Europe during the Great Recession (the emergence of parties difficult to place on the conventional spectrum of the left-right like the Five Star Movement, 
or the creation of a governing coalition in Greece in 2015 between the radical left and nationalist right) has acknowledged, without shedding the framework of the thin-centred ideology, the need for 'a more flexible and more broadly encompassing understanding' of populism, including not just the ideological dimension but also a discursive style and a political strategy (Kriesi and Pappas 2015). The point here is that policy positions of populist parties, including their foreign policy preferences, are not just derivative of the interaction between their thick ideological traditions and populism's thinness, but perhaps also of core characteristics of the logic of populist politics per se.

b) Populism in World Politics

Assessing populists' attitudes towards issues of world politics requires an understanding of what international conditions bring about populism. Various explanations have been offered on this. In mature developed economies populism has arisen over the last 30 years as a response to longstanding tendencies of hollowing out of accountable and representative democratic rule (Mair 2013), of economic diversification and modernization (Kitschelt 1995; Kriesi et al 2008; Rydgren 2013), and of social fragmentation and liberalization (Minkenberg 2000). In developing and emerging economies in the periphery and the semi-periphery on the other hand, populism represents a reaction to patterns of incorporation in the global economy that entail both socioeconomic hardship and a challenge to sovereignty and accountability of political rule (Aytaç and Öniş 2014; Hadiz and Chryssogelos 2017). To varying degrees all these phenomena have been related to globalization as the overarching structural condition of global politics since the end of the Cold War (Rodrik 2011).

Thus populism is something more than just reaction to hard economic times brought about by modernization. Michael Zürn's work on legitimacy of global governance is particularly pertinent here (Zürn 2004; Zürn et al 2012). Zürn identifies populism as a reaction to the denationalization of political rule and the depoliticization of global governance. As 'transgovernmental' global governance institutions bring together officials, operatives and bureaucrats of national administrations regulating the flows of globalization, populism expresses for Zürn a reaction of national societies against the 
collusion and escape of state apparatuses from popular control. Unlike transnational new politics movements that seek to re-politicize governance on the international level, populism represents politicization on the national level (Zürn 2004).

Zürn's conceptualization of populism as a reflection of the divide between state and society within a context of globalization evokes the insights of discursive approaches that see populism as a mode of antagonistic politics between the 'people' and 'power'. It is not a coincidence that many analyses of populism in the Global South that view it as a reaction to a globalized capitalist economy do so through this discursive/critical approach (Hadiz 2016). It is also telling that developments in populist politics in Europe that have opened up space for analyses of populism as a discourse (rather than an ideology) have been the result of broader structural shifts on a regional scale (the Eurozone crisis and economic recession) (Stavrakakis and Katsambekis 2014).

Thus the positioning of populism in an international framework also implies the broadening of the conceptual framing of populism as a phenomenon of world politics. For discursive and critical approaches the opposition between society and political power is the key feature of populism, thus it can also be given primacy in explaining preferences of populist movements in foreign policy. The mainstream comparative approach on the other hand traces foreign policies of populist parties to the interaction between the core tenets of populism and the thick ideological traditions they carry.

\section{POLITICAL PARTIES AND FOREIGN POLICY}

The question of populism in foreign policy is a subset of the question of the role of political parties in foreign policy. There are two broad strands of research on political parties in foreign policy, carrying their own sets of questions and implications for the role of populism in foreign policy: a strand that examines the effect of parties as carriers of specific ideological preferences on foreign policy, and a 
strand that examines the role of parties as an institutional parameter of foreign policy making. Both viewpoints find their application in works on the populism in foreign policy.

The first strand tries to explain partisan foreign policy preferences with reference to preferences on domestic governance. In this vein, Rathbun (2004) saw political parties' preferences in foreign policy as a direct reflection of their ideology. Depending on whether they are 'rightist' or 'leftist', political parties pursue exclusive interest-driven or inclusive values-driven foreign policies. Kaarbo (2012) has argued that right-wing coalitions tend to be more conflict-prone than left-wing ones. Thérien and Noël (2000) and Carbone (2007) see political parties playing an important role in development aid (with centre-left parties being more generous than centre-right ones), while Noël and Thérien (2008) argue that the agenda of international institutions in global economic governance reflects the fluctuating influence of ideologies of the left and right. Moving beyond the left-right divide, Ozkececi-Taner (2005) sees partisan positions on Turkish foreign policy as extension of specific political identities of domestic politics (e.g. nationalism, Islamism etc.), while Hofmann (2013) claims that the emergence of ESDP/CSDP in the 1990s can be traced back to policy ideas developed as parts of broader sets of partisan policy preferences.

In sum this approach sees partisan foreign policy positions as reflecting 'visions of domestic society' (Manow et al 2008). This has been a staple of literature about partisan positions on European integration (Marks and Wilson 2000). Of course in Europe EU integration has domesticated many policy areas, thus turning them from a matter of intergovernmental bargaining to one of ideological contestation. Yet deterritorialization of domestic policy and domestication of external policies affects all polities in the world. Whether affected by Europeanization or globalization, national foreign policies are becoming increasingly subject to domestic scrutiny and contestation akin to domestic policy issues (Verbeek and Van der Vleuten 2008). The importance of party politics for foreign policy increases accordingly. 
A parameter that affects how parties express their ideological preferences is the systemic character of party competition. Thus Verbeek and Zaslove (2015) take into account the dynamics of party competition in Italy to explain the varying capacity of the Lega Nord to inform the foreign policies of Italian governments it was a member of, while Chryssogelos (2015a) shows how the polarization of party competition in Greece crucially conditioned the content, pace and timing of important changes in its foreign policy towards Turkey.

The second strand of research in partisan foreign policy examines what kind of institutional settings allows parties to exert influence over foreign policy. Kaarbo's work on coalitions and foreign policy is indicative of this approach (Kaarbo 1996; 2008; 2012; Kaarbo and Beasley 2008). It is argued there that coalition governments tend to adopt more extreme foreign policy positions. Also, junior coalition partners can influence a government's foreign policy if they occupy relevant cabinet posts or if they can employ a credible threat to bring down a government. Elsewhere, Oppermann and Brummer (2014) compare the capacities and pathways for junior partners to influence coalition foreign policies in conservative-liberal cabinets in Germany and the UK.

\section{POPULISM AND FOREIGN POLICY: THE STATE OF THE ART}

Perhaps the first comprehensive comparative analysis on the foreign policy of populist parties is a volume on the foreign and security policy positions of the populist far right in Europe (Liang 2007). The findings point to a common policy profile of the populist far right in foreign policy, focused on Euroscepticism, anti-Americanism, fear of Muslim immigration and Islam more generally, opposition to Turkey's entry into the EU, and new security threats like terrorism. The populist right is interestingly not rejectionist of the role of Europe in foreign and security affairs. Rather, the populists of the right seem to have, next to a nationalist view, also a cultural perception of international affairs, hoping that Europeans will close ranks against multiculturalism at home and alien threats from abroad. As a reflection of their ethnopluralism - the notion that different ethnic groups and cultures must remain 
apart - Liang's volume sees right-wing populist parties promoting internationally a vision of globalized nationalism whereby distinct national groups join forces to oppose the homogenizing economic and cultural impact of globalization.

Populist foreign policy in Europe was also the focus of the work of Chryssogelos (2010; 2011). He identified a common populist profile in foreign policy spanning the right and left in the areas of transatlantic relations, Russia, and global governance (international institutions, aid, migration etc.). His findings were broadly aligned with those of Liang, as populists are united by a common negative attitude towards the US and globalization, a sceptic stance towards processes of global governance and military engagements outside of Europe, and a positive view of Russia's role in European security. The justifications for these policies however differed substantially between the populist right and left in reflection of their prior ideological rooting. Balfour (2016) also reaches similar conclusions, emphasizing particularly the unpredictability and contingency of populist positions on foreign policy in Europe.

The security crises in Georgia in 2008 and Ukraine in 2013-14 severely burdened EU-Russia relations and produced an intense interest in the ties between Russia and the European far right. Of interest here is both the political and personal ties between Russian actors close to the Kremlin and various actors of the far right in Europe, as well as the policy positions and the political support provided by populist parties to Russian actions (Balfour 2016; Political Capital 2014). While the focus with regards to Russia has been overwhelmingly on the populist right, the relations of the European populist left with Russia also recently gained attention due to the overtures of the Syriza-led Greek government during its renegotiation of its bailout agreement with the Eurozone ${ }^{1}$.

Verbeek and Zaslove (2015) examine the role of the Lega Nord in Italian foreign policy as a junior partner in various coalition governments between 1994 and 2011. Like Liang, they see LN's foreign policy as stemming from its ideological profile, including its opposition to immigration and its

\footnotetext{
${ }^{1}$ H Smith and A Luhn, 'Alexis Tsipras flies to Moscow amid speculation of bailout from Putin'. The Guardian, 8 April 2015.
} 
scepticism towards the role of the US in world affairs. Yet these predispositions can cue conflicting preferences - e.g. the $L N$ is Eurosceptic but at the same time expected the EU to help Italy deal with rising waves of migrants arriving to its shores. The LN's voter profile also played a role in its policy changes: the small manufacturers and family businesses that initially supported LN were positive towards the European market, but in recent years have turned much more fearful of globalization (see also Woods 2009).

Foreign policy inconsistency and change has been a common phenomenon in the foreign policy of European populists. During the Cold War the Front National was pro-NATO and anti-Soviet (Shields 2007). In the 1990s its relationship with Russia mostly had to do with contacts with likeminded nationalists. It only discovered Russia as a point of reference after relations between Moscow and the West soured in the late-00s. Similarly, a key feature of FPÖ's populism in Austria during the 1980s and 1990s was its support for Austria's entry into NATO, a position against Austria's well-established neutral identity (Meyer 2007). But from the early-00s onwards the FPÖ started shifting its foreign policy, opposing American interventionism and developing strongly pro-Russian positions. These changes have been usually attributed to populism's thinness and populist leaders' fickleness, but a closer examination of the French and Austrian cases shows that changes in the foreign policy positions of populist parties reflect conscious strategic decisions of these parties to reposition themselves in their countries' party competition (Chryssogelos 2015b).

There has been a long-standing debate about the relationship between populism and foreign policy in the US, which has intensified in recent years in response to the rise of the Tea Party and the election of Donald Trump to the presidency. Most typically populism, in its 1890 s agrarian variant and in its $20^{\text {th }}$ century incarnations, has been associated with economic protectionism (Krugman 1993) and political isolationism (Kazin 2016). Yet this would be an incomplete picture. In a highly interesting analysis of how the Populist Party saw foreign policy issues of the day (the war with Spain in 1898, the Boer War, and the great Indian famine), Amstutz shows agrarian populists as being highly interested 
in world affairs and mobilized on the side of 'republican government' and anti-imperialism, thus projecting abroad their ideas about popular sovereignty at home (Amstutz 2014).

Mead (2011) also offers a more sophisticated picture of American populism, which dislikes international institutions and needless sacrifices of US resources, but also believes in full-on military engagement if core American interests and security are threatened. In discussing the Tea Party, Mead claims that only a minority wing is principally isolationist, while its majority may reject the identification of US interests with the global institutional order but still understands the necessity of international engagement. This analysis seems to capture also the main themes of Donald Trump's 2016 presidential campaign, where he simultaneously advocated trade protectionism, dismissal of costly alliances and security guarantees, and an aggressive militaristic response to Islamic jihadism.

Analyses about populism and foreign policy in non-Western countries are rare. An interesting exception is Dodson and Dorraj (2008) who compare the foreign policies of Venezuela and Iran under two populist leaders: Hugo Chavez and Mahmoud Ahmadinejad. These populist leaders were united by anti-imperialism and the fear that the US intended to destabilize the domestic order they were defending - the Bolivarian socialist revolution in Venezuela and the theocratic Islamic regime in Iran. As a result, they saw foreign policy as an instrument to stave off US efforts to undermine their domestic regimes. They did so by making use of the advantages conferred by their oil resources (on 'resource populism' see also Tsafos 2007) and engaging in regional alliance-making and institution building. Dodson and Dorraj stress the importance of Americanismo - the ideology of Latin American unity forged through a shared experience of European colonialism and exploitation by the US - for Chavist populism (see here also Ellis, 2014 and Hawkins, 2016), while Ahmadinejad's regional foreign policy in the Middle East bolstered Iran's image as an anti-imperialist force among developing states and the Muslim world.

This review shows that the literature on populism in foreign policy is still relatively small but rapidly growing. Building (implicitly or explicitly) on the main insights of the literature on political 
parties and foreign policy, most of these analyses embark from the view that partisan foreign policies are extrapolations of preferences on domestic policy issues. Populist radical right parties in Europe for example oppose international developments that they see as threatening their idealized vision of the political community, e.g. increase of immigration or the deepening of European integration that threatens national sovereignty. The same mechanism is at play with the foreign policy of populist left parties, whose anti-Americanism and scepticism towards the institutions of global governance reflects their opposition to neoliberal economics at home.

Existing research on populism in foreign policy also draws on FPA considerations about the role of political parties in coalition politics, examining the role of populist parties in coalition foreign policy. This is facilitated by the fact that in Europe, where most of this research focuses on, populist parties have found themselves in office primarily in coalition with mainstream parties (starting in the early 2000s, this has been the case in Austria, Switzerland, Italy, Norway, Denmark and the Netherlands) (Heinisch 2003). There may be a need for a shift in focus however as populist parties are entrenching themselves in European party systems and are forming single-party governments (e.g. Poland) or dominate coalition governments (e.g. Greece).

Also most of the literature on populism in foreign policy prioritizes the dominant comparative approach that views populism as a thin-centred ideology that is given a precise content by its association with thicker ideological traditions (see Verbeek and Zaslove forthcoming). This approach helps detect similarities and differences within party families (e.g. the populist radical right), as well as between them (e.g. the populist right and the populist left). By updating and revamping older authoritarian ideologies and traditions of European politics, populism allows the far right and the far left's positions on migration, security, globalization and capitalism to find a place in contemporary public discourse (Chryssogelos 2011). 
Despite the important new ground these works have broken, the global proliferation of populism and its increased relevance in academic and public debates on international affairs (Foreign Affairs 2016) call for some reappraisal of established approaches in the study of populism in foreign policy. It is unclear for example how well the 'thin-centred ideology' approach accommodates newly emergent and increasingly varied populisms. Of course one can still identify thicker ideologies that inform populist movements in other regions, such as Americanismo (Mudde and Rovira Kaltwasser 2011) or Islamism (Hadiz 2016).

But perhaps it is not always helpful to relegate the core ideological elements of populism (however thin) to the background. This is particularly true not only of the Global South (where traditions of thick ideologies such as liberalism or socialism are weaker), but even of Europe. The success of populist parties like SYRIZA in the Eurozone crisis has after all been convincingly interpreted on the basis of their capacity to make broader interpellations along a people-elite cleavage that transcends prior ideological divides (Stavrakakis and Katsambekis, 2014).

In the US on the other hand populism is seen both as the ideology of a specific political party - the Populists of the $1890 \mathrm{~s}$ - and as a diffuse political culture that postulates a popular challenge against elites and that may take different forms and orientations (nativist-exclusivist or economic-reformist). In non-Western countries, it is unclear what other ideology such leaders as e.g. Thaksin Shinawatra in Thailand (Phongpaichit and Baker 2008) or Michael Sata in Zambia (Fraser 2017) represented apart from a distinct antagonistic appeal for mobilization on the basis of a division between 'the people' and 'power'. The point here is that scholars of foreign policy can focus not simply on how populism helps promote prior thicker ideological traditions, but on whether foreign policy positions are themselves the function of traits of populist ideology tout court.

One can for example interpret populist foreign policies on the basis of how opposition to elites at home is underpinned by opposition to elites internationally. Opposition to elites at home and abroad can explain the anti-American turn of populist parties in Europe after the end of the Cold War, since 
the US became the undisputed superpower and populists could associate it with a variety of policies they opposed - free trade, loss of sovereignty, cultural homogenization etc. Some parties of the populist radical right in Europe have rebranded the historical anti-Semitism of the European far right when commenting on the Israel-Palestine conflict as support for Palestinians as the underdogs against an oppressor (Israel). Other times, and depending on whether they have wanted to present Islam as the biggest threat to the 'people', they have also presented Israel as the underdog in its fight with radical Islam (Chryssogelos 2011; Liang 2007).

The emergence not just of populist movements but of populist governments in various parts of the world also presents new empirical puzzles. Trump is the latest and most prominent example of course, and Latin America has a long experience with populists in power. Already some scholars have engaged in cross-regional comparisons not simply of populist movements but of populists in power (Aytaç and Öniş, 2014). But over the last 15 years many world leaders have attracted the characterization of 'populist' as they try to justify their own entrenchment in power by using foreign policy to polarize against the West (Dodson and Dorraj 2008, Robinson and Milne 2017).

Depending on the local context or their rooting in thicker ideological traditions, populist parties' understanding of the people to be protected and represented and the 'heartland' they look back to (Taggart 2000) will differ. Variation along this dimension may have important influence on foreign policy. Populist parties and movements are most commonly associated with reaction to institutions and processes on the international or transnational level that undercut political representation and accountability of national authorities.

The Euroscepticism of the populist radical right is a case in point here, but the attitudes of the populist left that has emerged in the years of the Eurozone crisis are also of interest. In his first months in power Alexis Tsipras pursued a renegotiation of the terms of financing of the Greek debt that took little account of the preferences of Greece's partners. In Spain, Pablo Iglesias of Podemos calls himself 
(somewhat unexpectedly for a leftist) a soberanista (Gerbaudo 2016; see here especially Halikiopoulou et al 2012).

But populist foreign policy positions may also be informed by conceptualizations of the people that transcend national borders. This is important for the foreign policy positions of populists. The US Populist Party's conceptualization of the 'people' in the 1890s was broad enough to encompass struggles for sovereignty all over the world (Amstutz 2014). More recently, populists in the Global South have often defined the 'people' in ways that betray regional or global aspirations. The left-wing populisms of the 2000s in Latin America defined the people on the basis of Latin America and its experience of exploitation by Europe and the US (the ideology of Americanismo, see Mudde and Rovira Kaltwasser 2011). This in turn informed foreign policy positions that were adversarial to the US and led to attempts to create new structures of regional cooperation in Latin America (Ellis 2014, Hawkins 2016). Mahmud Ahmadinejad aimed to speak for the Muslim world, the Middle East and the whole Global South against the US and the West (Dodson and Dorraj 2008). Recep Tayip Erdogan's populism defines the people as the global Islamic umma (Hadiz 2016), which informs, along with Turkey's Ottoman past, his regional and global ambitions for Turkish foreign policy.

Foreign policy analysts interested in populism can also draw interesting insights by looking at broader areas of foreign policy beyond just political, diplomatic or security issues. Immigration has long been a marker issue for the European populist radical right, but economic matters, particularly trade, are also growing in importance (Verbeek and Zaslove forthcoming). The promise of both the Trump and the Brexit campaigns to 'take back control' in immigration and the voluntarism of the US and UK governments as they aggressively look for 'good trade deals' ${ }^{2}$ are indicative of a mind-set that prioritizes immediate national interests to the detriment of international institutions and rules (Verbeek and Zaslove 2015). This in turn reflects populism's well known anti-institutionalist bent,

\footnotetext{
2 Henry Austin, 'Theresa May Looking Forward to Pursuing Trade Deal with Donald Trump.' The Independent, 26 January 2017, http://www.independent.co.uk/news/uk/politics/brexit-latest-theresa-may-donald-trump-trade-deal-europeanunion-eu-us-a7548511.html, accessed 2 April 2017.
} 
prioritizing as it does the will of the people against institutionalized decision-making processes, consensus, checks and balances etc. (Meny and Surel 2002).

It is important here then to differentiate between populism and isolationism in foreign policy. Populists do not necessarily promote a principled shielding off from the rest of the world. What they represent - both in the West and the Global South - is a reaction to processes of dilution of popular sovereignty (Amstutz 2014). Coming back to Zürn's (2004) conceptualization, populism seeks to repoliticize global affairs by promoting a direct relationship, unshackled by complex processes of rulemaking and governance practices, between the 'people' (nationally or transnationally defined) and international politics. In practical terms this means that populists will engage with the world, but only in terms that favour immediate national interests and do not entail sacrifices for the sake of broader milieu goals (Mead 2011). By the same token, populism need not equal trade protectionism (though this is very often the case); populists like free trade if it does not entail material sacrifices (Verbeek and Zaslove, forthcoming).

\section{SUGGESTIONS FOR FURTHER RESEARCH}

Populism and foreign policy is an underexplored and relatively neglected sub-field in FPA. But this means that there are exciting opportunities for sophisticated and relevant research in the future, especially at the time when politicians, opinion-makers and the lay public are eagerly trying to discern patterns and implications of the global rise of populism for international politics. The contested and slippery nature of the concept of populism is both an obstacle and an advantage: it hampers the emergence of an unambiguous and clear conceptualization of populism, but it provides the leeway for eclectic theorizing that may accommodate varying iterations of populism in multiple world regions and help explain policy stances that sometimes seem inconsistent and fickle. 
Thus one suggestion is for scholars of foreign policy to engage with the whole breadth of conceptual approaches of populism - ideological, discursive, critical etc. While the 'thin-centred ideology' approach has proven extremely useful in incorporating populism in comparative research of foreign policy in Europe, the increasing variability and global spread of the populist phenomenon call for a broadening of the conceptual horizon. Depending on their empirical focus and theoretical preferences, foreign policy analysts may also want to follow critical and discursive approaches that have been quite apt at relating populism to developments of global politics - particularly as a reaction to dislocations of globalization.

The second point is for scholars to broaden not just their conceptual but also their empirical and geographical reach, and to think about populism as a factor of foreign policy in all world regions (Europe and Latin America, but also North America, Asia, Middle East and Africa). Most comparative work on populism in foreign policy focuses on Europe, where populists have rarely been in power (although this has changed in recent years) and are generally weaker than elsewhere (Mudde and Rovira Kaltwasser 2011). But some of the most significant populist leaders for foreign policy have emerged outside of Europe (Iran, Venezuela, Turkey, and now the US). The insights of the growing literature on cross-regional comparisons of populism will be very useful for FPA scholars here (Phongpaichit and Baker 2008).

Needless to say, the broadening of the conceptual and the empirical agenda does not imply two parallel and unrelated processes. It is interesting for example how much the immense literatures on populism in the US and populism in Europe have evolved with little reference to each other. But ongoing developments in the politics of both the US and Europe shows that populist phenomena on both sides of the Atlantic increasingly influence, and perhaps feed off, each other (e.g. the Trump and Brexit campaigns). It is important for scholars in the US and Europe to become more informed and articulate in the other's experience with populism, thus informing and challenging their own 
theoretical preconceptions of this phenomenon. This in turn may generate a fuller view of what populism means for world politics and foreign policy.

\section{CONCLUSION}

Populist parties, movements and leaders seem to emerge primarily under conditions of concurrent crises of economic performance and political representation (Hadiz and Chryssogelos 2017). To the extent that this simultaneous political and economic crisis is conditioned by a state's relative position towards overarching international conditions and shifts such as globalization (Rodrik 2011), the positioning of populists towards the international sphere is more important than what appears initially.

Of course one cannot speak of one populist foreign policy today. The ideological variability of populist parties and movements is too big, and their capacity to influence foreign policy also varies. Populist parties pursue foreign policies that reflect their domestic preferences and values, but these are mediated by institutional and party system structures (just like the foreign policy preferences of other parties). It is generally difficult to extrapolate foreign policy positions of likeminded ideological parties from their domestic preferences, when states are faced with diverse challenges that make comparability across time and between cases difficult.

That said, one can still identify some basic principles of what constitutes a populist streak of foreign policy. Populists tend to view the world via the lens of the opposition between the people and the elites. They have a sense of sovereignty against global and transnational political and economic forces; their 'people' is usually defined along national lines (thus their foreign policy may also be described as 'nationalist') (Halikiopoulou et al 2012) but this is not always the case, particularly with populists from the Global South who may speak for broader constituencies (Latin America, the Muslim world etc.). 
Populists tend to be anti-Western to the extent that the dominant political and institutional arrangements of post-Cold War international politics are identified with the West (Ellis 2014). Populists from the Global South will call for these institutions to be made more representative, while populists in the West will oppose the loss of national sovereignty and the political and economic costs the 'people' have to undergo to sustain this system. Populists are not isolationists in principle, but transpose to the international sphere their distrust for complex policymaking procedures. They politicize world politics the same way they radicalize domestic politics, prioritizing the will of the people against norms of efficiency, consensus and institutional checks and balances.

The exact content of populist foreign policies will differ according to the thicker ideologies these parties and movements express. The view of populism as a thin-centred ideology predominates in comparative analyses of populism and has informed most work on the role of populism in foreign policy. While these works have created important advances in the study of populism in FPA, it is also worth analyzing populist foreign policy taking into account the independent effect of populism on the policy preferences of populist parties. Thus FPA scholars can also look into critical and discursive works as a way to enrich their understanding of populism, as well as broaden the empirical scope of their comparisons and analysis.

Given the global proliferation of populism and the increasing realization among policymakers and the lay public that it is a very consequential phenomenon for international relations, this broadening of the theoretical and empirical agenda in the study of populism in foreign policy is today more necessary than ever.

\section{LIST OF REFERENCES}

Albertazzi, D and D McDonnell (eds) (2008) Twenty-First Century Populism. The Spectre of Western European Democracy. New York: Palgrave MacMillan. 
Amstutz, DL (2014) A Populist Approach to Foreign Policy: Governor William A. Poynter, the South African War, and the Indian Famine, 1899-1901. Great Plains Quarterly 34(1): 11-34.

Aytaç, SE and Z Öniş (2014) Varieties of Populism in a Changing Global Context: The Divergent Paths of Erdoğan and Kirchnerismo. Comparative Politics 47(1): 41-59.

Balfour, R (rapporteur) (2016) Europe's Troublemakers. The Populist Challenge to Foreign Policy. Brussels: European Policy Centre.

Betz, H-G (1993) The New Politics of Resentment. Radical Right-Wing Populist Parties in Western Europe. Comparative Politics 25(4): 413-427.

Canovan, M (1999) Trust the People! Populism and the Two Faces of Democracy. Political Studies $47(1): 2-16$.

Carbone, M (2007) The Domestic Foundations of Italy's Foreign and Development Policies. West European Politics 30(4): 903-923.

Chryssogelos, AS (2010) Undermining the West from Within: European Populists, the US and Russia. European View 9(2): 267-277.

Chryssogelos, AS (2011) Old Ghosts in New Sheets. European Populist Parties and Foreign Policy. Brussels: Centre for European Studies.

Chryssogelos, AS (2015a) Foreign Policy Change in a Polarized Two-Party System: Greece and Turkey's EU Candidacy. Southeast European and Black Sea Studies 15(1): 19-36.

Chryssogelos, AS (2015b) Reaction and Adaptation in the Longue Durée: The Far-Right, International Politics and the State in Historical Perspective. In Saull, R et al (eds.), The Longue Durée of the FarRight. London: Routledge: 85-105.

Dodson, M and M Dorraj (2008) Populism and Foreign Policy in Venezuela and Iran. Whitehead Journal of Diplomacy and International Relations 9: 71-87. 
Ellis, RE (2014) Latin America's Foreign Policy as the Region Engages China. Security and Defense Studies Review, 15(1): 41-59.

Foreign Affairs (2016) The Power of Populism. Foreign Affairs, 95(6), November/December.

Gerbaudo, P (2016) Post-Neoliberalism and the Politics of Sovereignty. Open Democracy, 4 November 2016. https://www.opendemocracy.net/paolo-gerbaudo/post-neoliberalism-and-politics-ofsovereignty, accessed 21 November 2016.

Fraser, A (2017) Post-Populism in Zambia: Michael Sata's Demise, and Legacy. International Political Science Review, forthcoming special issue.

Hadiz, V (2016) Islamic Populism in Indonesia and the Middle East. Cambridge: Cambridge UP.

Hadiz, V and A Chryssogelos (2017) Populism in World Politics: A Comparative Cross-Regional Perspective. International Political Science Review, forthcoming special issue.

Halikiopoulou, D, K Nanou and S Vasilopoulou (2012) The Paradox of Nationalism: The Common Denominator of Radical Right and Radical Left Euroscepticism. European Journal of Political Research 51(4): 504-539.

Hawkins, KA (2016) Responding to Radical Populism: Chavismo in Venezuela. Democratization 23(2): $242-262$.

Heinisch, R (2003) Success in Opposition, Failure in Government: Explaining the Performance of RightWing Populist Parties in Public Office. West European Politics 26(3): 91-130.

Hofmann, SC (2013) European Security in NATO's Shadow. Party Ideologies and Institution Building. Cambridge: Cambridge University Press.

Hofstadter, R (1955) The Age of Reform: From Bryan to FDR. New York: Knopf.

Ionescu, G and E Gellner (eds) (1969) Populism. Its Meaning and National Characteristics. London: Weidenfeld and Nicolson. 
Kaarbo, J (1996) Power and Influence in Foreign Policy Decision Making: The Role of Junior Coalition Partners in German and Israeli Foreign Policy. International Studies Quarterly 40(4): 501-530.

Kaarbo, J (2008) Coalition Cabinet Decision Making: Institutional and Psychological Factors. International Studies Review 10(1): 57-86.

Kaarbo, J (2012) Coalition Politics and Cabinet Decision Making: A Comparative Analysis of Foreign Policy Choices. Ann Arbor: University of Michigan Press.

Kaarbo, J and RK Beasley (2008) Taking It to the Extreme: the Effect of Coalition Cabinets on Foreign Policy. Foreign Policy Analysis 4(1): 67-81.

Kezin, M (2016) Trump and American Populism: Old Whine, New Bottles. Foreign Affairs 95(6).

Kitschelt, H (1995) The Radical Right in Western Europe. A Comparative Analysis. Ann Arbor: University of Michigan Press.

Kriesi, H, Grande, E, Lachat, R, Dolezal, M, Bornschier, S and T Frey (2006) Globalization and the Transformation of the National Political Space: Six European Countries Compared. European Journal of Political Research 45(6): 921-956.

Kriesi, H, Grande, E, Lachat, R, Dolezal, M, Bornschier, S and T Frey (2008) West European Politics in the Age of Globalization. Oxford: Oxford University Press.

Kriesi, H and TS Pappas (eds) (2015) European Populism in the Shadow of the Great Recession. Colchester: ECPR Press.

Krugman, P (1993) The Uncomfortable Truth about NAFTA: It's Foreign Policy, Stupid. Foreign Affairs 72(5): 13-19.

Laclau, E (2005) On Populist Reason. London: Verso.

Mair, P (1997) Party System Change. Approaches and Interpretations. Oxford: Clarendon Press. 
Mair, P (2009) Representative versus Responsible Government. MPIfG Working Paper 09/8. Cologne: Max Planck Institute for the Study of Societies.

Mair, P (2013) Ruling the Void. The Hollowing-Out of Western Democracy. London: Verso.

Manow, P, Schäfer, A and H Zorn (2008) Europe's Party-Political Centre of Gravity, 1957-2003. Journal of European Public Policy 15(1): 20-39.

March, L (2007) From Vanguard of the Proletariat to Vox Populi. Left-Populism as a "Shadow" of Contemporary Socialism. SAIS Review of International Affairs 27(1): 63-77.

March, L and C Mudde (2005) What's Left of the Radical Left? The European Radical Left after 1989: Decline and Mutation. Comparative European Politics 3(1): 23-49.

Marks, G and CJ Wilson (2000) The Past in the Present: A Cleavage Theory of Party Response to European Integration. British Journal of Political Science 30(3): 433-459.

Mead, WR (2011) The Tea Party and American Foreign Policy: What Populism Means for Globalism. Foreign Affairs 90(2): 28-44.

Meny, Y and Y Surel (2002) Democracies and the Populist Challenge. New York: Palgrave MacMillan.

Meyer, B (2007) Austria between Felt Permanent Neutrality and Practiced European Enlargement. Frankfurt: Peace Research Institute.

Minkenberg, M (2000) The Renewal of the Radical Right. Between Modernity and Anti-Modernity. Government and Opposition 35(2): 170-188.

Mudde, C (2004) The Populist Zeitgeist. Government and Opposition 39(4): 542-563.

Mudde, C (2007) Populist Radical Right Parties in Europe. Cambridge: Cambridge University Press.

Mudde, C and K Rovira Kaltwasser (2011) Voices of the Peoples: Populism in Europe and Latin America Compared. Working Paper \#378. Kellogg Institute for International Studies. 
Noël, A and JP Thérien (2008) Left and Right in Global Politics. Cambridge: Cambridge UP.

Nugent, WTK (1963) The Tolerant Populists. Kansas Populism and Nativism. Chicago: Chicago UP.

Oppermann, K and K Brummer (2014) Patterns of Junior Partner Influence on the Foreign Policy of Coalition Governments. British Journal of Politics and International Relations 16(4): 555-571.

Ozkekeci-Taner, B (2005) The Impact of Institutionalized Ideas in Coalition Foreign Policy Making: Turkey as an Example, 1991-2002. Foreign Policy Analysis 1(3): 249-278.

Panizza, F (ed) (2005) Populism and the Mirror of Democracy. London: Verso.

Phongpaichit P and C Baker (2008) Thaksin's Populism. Journal of Contemporary Asia 38(1): 62-83.

Political Capital (2014) The Russian Connection. The Spread of pro-Russian Policies in the European Far Right. Budapest: Political Capital Institute.

Rathbun, BC (2004) Partisan Interventions. European Party Politics and Peace Enforcement in the Balkans. Ithaca: Cornell University Press.

Roberts, KM (2007) Latin America's Populist Revival. SAIS Review of International Affairs 27(1): 3-15.

Robinson, N and H Milne (2017) Populism and Political Development in Hybrid Regimes: Russia and the Development of Official Populism. International Political Science Review, forthcoming special issue.

Rodrik, D (2011) The Globalization Paradox: Democracy and the Future of the World Economy. London: WW Norton.

Rydgren, J (ed) (2013) Class Politics and the Radical Right. London and New York: Routledge.

Schori Liang, C (ed) (2007) Europe for the Europeans. The Foreign and Security Policy of the Populist Radical Right. London and New York: Routledge. 
Shields, JG (2007) The Extreme Right in France. From Petain to Le Pen. London and New York: Routledge.

Shils, E (1956) The Torment of Secrecy. Glencoe: The Free Press.

Stavrakakis, Y (2014) The Return of "the People": Populism and Anti-Populism in the Shadow of the European Crisis. Constellations 21(4): 505-517.

Stavrakakis, Y and G Katsambekis (2014) Left-Wing Populism in the European Periphery: the Case of SYRIZA. Journal of Political Ideologies 19(2): 119-142.

Stewart, A (1969) The Social Roots. In Ionescu, G and E Gellner (eds) Populism: Its Meanings and National Characteristics. London: Weidenfeld and Nicolson: 180-196.

Taggart, P (2000) Populism. Buckingham: Open University Press.

Thérien, JP and A Noël (2000) Political Parties and Foreign Aid. American Political Science Review. 94(1): 151-162.

Tsafos, NE (2007) Big Oil and Big Talk: Resource Populism in International Politics. SAIS Review of International Affairs 27(1): 147-157.

Verbeek, B and A van der Vleuten (2008) The Domesticization of the Foreign Policy of the Netherlands (1989-2007). The Paradoxical Result of Europeanization and Internationalization. Acta Politica 43(2): 357-377.

Verbeek, B and A Zaslove (2015a) The Impact of Populist Radical Right Parties on Foreign Policy: the Northern League as a Junior Coalition Partner in the Berlusconi Governments. European Political Science Review 7(4): 525-546.

Verbeek, B and A Zaslove (forthcoming) Populism and Foreign Policy. In Taggart, P and C RoviraKaltwasser (eds.) Handbook of Populism. 
Weiss, J (1977) Conservatism in Europe 1770-1945. Traditionalism, Reaction and Counter-Revolution. London: Thames and Hudson.

Weyland, K (2001) Clarifying a Contested Concept: Populism in the Study of Latin American Politics. Comparative Politics 34(1): 1-22.

Woods, D (2009) Pockets of Resistance to Globalization: The Case of the Lega Nord. Patterns of Prejudice, 43(2): 161-177.

Zürn, M (2004) Global Governance and Legitimacy Problems. Government and Opposition 39(2): 260287.

Zürn, M, M Binder and M Ecker-Ehrhardt (2012) International Authority and its Politicization. International Theory 4(1): 69-106. 